\title{
Characterization of rat lung ICAM-1
}

\author{
B. Beck-Schimmer ${ }^{1,2}$, R. C. Schimmer ${ }^{1,3,4}$, H. Schmal ${ }^{1}$, C. M. Flory ${ }^{4}$, H. P. Friedl ${ }^{3}$, T. Pasch ${ }^{2}$ and P. A. Ward $^{1}$ \\ ${ }^{1}$ Department of Pathology, University of Michigan Medical School, 1301 Catherine Road, Ann Arbor, MI 48109-0602 USA, Fax +1 734763 4782, \\ e-mail: pward@umich.edu \\ ${ }^{2}$ Institute for Anesthesiology, University of Zurich Medical School, Rämistr. 100, CH-8091 Zurich, Switzerland \\ ${ }^{3}$ Department of Surgery, University of Zurich Medical School, Rämistr. 100, CH-8091 Zurich, Switzerland \\ ${ }^{4}$ Department of Immunopathology, Parke Davis Pharmaceutical Research, Division of Warner Lambert Company, 2800 Plymouth Road, \\ Ann Arbor, MI 48105, USA
}

Received 19 February 1998; returned for revision 25 March 1998; accepted by G. W. Carter 17 April 1998

\begin{abstract}
Objective and Design: We expressed soluble rat ICAM-1, generated a polyclonal anti-ICAM-1 antibody, and studied ICAM-1 upregulation in lung inflammatory conditions. Bacterial and baculovirus expression systems were employed.

Material: $250 \mathrm{~g}$ adult, male Long Evans rats were used. For in vitro studies, rat pulmonary artery endothelial cells (RPAEC), rat alveolar macrophages and aortic rings were stimulated (as described below) and evaluated for ICAM-1 expression.

Treatment: RPAEC and macrophages were stimulated with lipopolysaccharide (LPS) and recombinant murine tumour necrosis factor $\alpha(\mathrm{TNF} \alpha)$. In vivo immunoglobulin $\mathrm{G}(\mathrm{IgG})$ immune complex-induced lung injury was employed.

Methods: Enzyme-linked immunoassay (ELISA) Western and Northern blot analyses and immunohistochemical evaluations were performed. All experiments were done at least in duplicate. Data were analyzed by two-tailed Student's t-test.

Results: ICAM-1 expression of RPAEC was time- and dosedependent, peaking at $6 \mathrm{~h}$ after LPS-stimulation. LPS and $\mathrm{TNF} \alpha$ each enhanced ICAM-1 expression on alveolar macrophages (reaching a maximum at $2 \mathrm{~h}$ ). In IgG immune complex-induced lung injury, ICAM-1 mRNA isolated from whole lung peaked at $4 \mathrm{~h}$, while lung ICAM-1 protein peaked at $6 \mathrm{~h}$.

Conclusions: Quantitation of ICAM-1 expression in vitro and in vivo suggests that ICAM-1 plays a central role in two lung inflammatory models. Furthermore, lung ICAM-1 upregulation involves at least two cell types: vascular endothelial cells and alveolar macrophages.
\end{abstract}

Key words: Rat ICAM-1 - Anti-ICAM-1 - Protein expression - Lung inflammation

Correspondence to: P. A. Ward

\section{Introduction}

The adhesion molecule ICAM-1 (CD54), a member of the immunoglobulin superfamily, is constitutively expressed on endothelial and epithelial cells, and to a lesser extent on leukocytes. As shown in several lung models of pulmonary inflammation [1-3], ICAM-1 plays a major role in leukocyte recruitment to inflammatory sites [4]. In the animal models employed, one of the first steps in leukocyte migration into tissues is engagement of neutrophils with endothelial Eselectin, which facilitates leukocyte 'rolling' on the activated endothelium. This is followed by interaction of endothelial ICAM-1 with leukocyte LFA-1 (CD11a/CD18) (and perhaps Mac-1, (CD11b/CD18)), which induces a firm adhesion and blocks further rolling of neutrophils. Neutrophil transmigration through the endothelium is then aided by endothelial products such as platelet activating factor (PAF) and IL-8 or its homologues, which appear to stimulate adherent neutrophils. In addition, endothelial platelet endothelial cell adhesion molecule-1 (PECAM-1) facilitates leukocyte adhesion to basolateral junctions of endothelial cells [5]. Precisely what chemotactic factors facilitate neutrophil transmigration is still a matter under study. The extensive studies of Wawryk et al. [6] have helped to delineate the interactions between human ICAM-1 and leukocytes.

In order to precisely and thoroughly quantitate ICAM-1 message and protein in two lung inflammatory models, rat ICAM-1 was cloned. Cloned DNA (cDNA) for rat ICAM-1 was used to express ICAM-1 in two different cell expression systems and the purified product used to immunize rabbits to generate antibody that could be used in ELISA assays, in immunostaining methodologies, and in in vivo blocking experiments. Since rat cDNA and recombinant rat ICAM-1 are largely unavailable, we developed these reagents and applied them in vitro and in vivo in order to obtain detailed information about the amounts of rat-ICAM-1 message and protein expressed and the cell sources of rat ICAM-1. In all of these studies, precise, quantitative endpoints were used as indicated. The studies to be presented indicate that in the inflamed lung there are at least two different cell sources of 
ICAM-1. Measurements of lung ICAM-1 message RNA (mRNA) and protein provide a detailed analysis of the response of the inflamed lung.

\section{Materials and methods}

\section{Protein expression in the bacterial system}

The cDNA from one of the selected full-length rat ICAM-1 cDNA libraries was sequenced and compared with already published data [7]. A partial length construct of $618 \mathrm{bp}$ was used, containing the ligand binding sites for LFA-1 and Mac-1. DNA was amplified by polymerase chain reaction (PCR) adding the primers for the expression vector. Restriction enzyme sites, NdeI $5^{\prime}$ and XhoI $3^{\prime}$, were incorporated into the following sequences: 5'-CAT ATG Nde CCT CTG CCC GCC TGG- $3^{\prime}$ and $3^{\prime}$-TGG GAC TCG GTC GGC ACT Xho GAG CTC-5'. The DNA was ligated into the pET $14 \mathrm{~b}$ vector (Novagen Inc., Madison, WI, USA) and closed into E. coli pLysS (Invitrogen, Inc., Carlsbad, CA, USA). For protein expression the cells were stimulated with $0.4 \mathrm{mM}$ isopropylthiogalactoside (IPTG) (Gibco Co., Grand Island, NY, USA) at different bacterial densities (0.6-0.8) and for different periods $(1 \mathrm{~h}-3 \mathrm{~h})$ to achieve the optimal protein production. The soluble protein was purified over a nickel column (His bind resin, Novagen, Inc.) and eluted with several imidazole concentrations $(100 \mathrm{mM}, 200 \mathrm{mM}$, $300 \mathrm{mM}$ ). Dialysis in phosphate-buffered saline (PBS), $\mathrm{pH} 7.0$ at $4{ }^{\circ} \mathrm{C}$ was performed and the product concentrated using Centricon Concentrators ${ }^{\circledR}$ (Amicon Co., Beverly, MA, USA).

\section{Protein expression in the baculovirus}

This procedure is similar to one described previously [8-10]. Briefly, the same template (as described above) was created for this vector but the restriction sites were changed to XmaI $5^{\prime}$ and BamHI $3^{\prime}$ according to the vector pPBac (Stratagene Inc., LaJolla, CA, USA): 5'-CCC GGG Xma CCT CTG CCC GCC TGG-3' and $3^{\prime}$-TGG GAC TCG GTC GGC ACT BamH CCT AGG-5' [11]. For transfection, the ICAM-1 bearing transfer vector was mixed with linear wild-type autographa californica nuclear polyhedrosis virus (AcMNPV) and SF-21 cells (Invitrogen Inc.) $\left(2 \times 10^{6}\right.$ cells in a $60 \mathrm{~mm}$ plate). Three plaque purification assays were performed. Amplification of the virus was achieved by infecting SF-9 cells. For optimal protein expression, SF-9 cells were infected and incubated for 4 days $[9,10]$. The cells and supernatant fluids were harvested and centrifuged (1500 rpm, $10 \mathrm{~min}$ ), washed in $50 \mathrm{mM}$ Tris $/ \mathrm{Cl}(\mathrm{pH}=7.0)$ containing $1 \mathrm{mM}$ dithiothreitol and $250 \mathrm{mM}$ sucrose, resuspended in $0.1 \mathrm{ml}$ Tris $/ \mathrm{Cl}(50 \mathrm{mM}, \mathrm{pH} 7.0)$, $1 \mathrm{mM}$ dithiothreitol and $0.5 \mathrm{mM} \mathrm{NaCl}$ and lysed by freezing and thawing 5 times in liquid nitrogen. DNA shearing was performed by five passes through a 25 -gauge needle. The supernatant fluids and cell lysates were analyzed by Western blot and run over an affinity column loaded with the polyclonal ICAM-1 antibody, followed by elution under acidic conditions.

\section{Western blot analysis}

Characterization of proteins was performed using sodium dodecyl sulfate/polyacrylamide gel electrophoresis (SDS/PAGE) under both reducing and nonreducing conditions. $5 \mu \mathrm{l}$ of Laemmli buffer were added to $20 \mu$ l of protein sample and loaded on gels (7.5 or 15\%). After electrophoresis, the gels were either stained with Coomassie blue [12] or transferred to nitrocellulose membranes (Bio Rad Inc., Hercules, CA, USA). The membranes were blocked with $3 \%$ bovine serum albumin (BSA) in tris-buffered saline (TBS), incubated with the murine or rabbit ICAM-1 antibody at a dilution of 1:500 and then incubated with a 1:3000 dilution of goat anti-murine or goat anti-rabbit alkaline phosphatase-conjugated antibody (Bio Rad Co. Inc.), followed by color reagents $\mathrm{A}$ and $\mathrm{B}$.

\section{ELISA quantitation of ICAM-1 on RPAEC and alveolar macrophages}

This assay was performed as described previously [13]. Briefly, 96 well microtiter plates were coated with $5 \times 10^{6}$ RPAEC per well and cultured overnight at $37^{\circ} \mathrm{C}$ in $5 \% \mathrm{CO}_{2}$. The cells were stimulated with LPS using varying concentrations or durations. Fixation was performed with $1 \%$ paraformaldehyde for $10 \mathrm{~min}$. For each washing step, PBS supplemented with $2 \%$ heat-inactivated fetal calf serum and $1 \%$ Tween 20 was used. After fixation, a blocking step of 5\% nonfat dry milk was added. The biotinylated polyclonal ICAM-1 antibody (Pierce Co., Rockford, IL, USA, ImmunoPure NHS-LC-Biotinylation Kit) was used at a dilution of 1:100 $\left(60 \mathrm{~min}, 37^{\circ} \mathrm{C}\right)$. The plate was washed three times and streptavidin-horseradish-peroxidase was added at a concentration of $0.1 \mu \mathrm{g} / \mathrm{ml}$ for $15 \mathrm{~min}$ at room temperature.

Macrophages from bronchoalveolar lavage (BAL) fluids from rat lungs were placed into 96 well plates $\left(5 \times 10^{5}\right.$ cells/well $)$ and stimulated with increasing concentrations of recombinant murine TNF $\alpha(5,10,20$, 50 and $100 \mathrm{ng} / \mathrm{ml}$ ). The subsequent steps were the same as described above. A similar study was performed, using $5 \mu \mathrm{g} / \mathrm{ml}$ LPS instead of $\mathrm{TNF} \alpha$. The macrophages were stimulated for $2,4,6$ and $8 \mathrm{~h}$ with LPS and subsequently fixed.

\section{Immunohistochemical and immunofluorescent analysis of rat endothelial cells and aortic rings}

RPAEC were plated at a density of $1 \times 10^{5}$ per chamber in Lab Tek ${ }^{\circledR}$ chamber slides (Nunc Co., Naperville, IL, USA) and cultured overnight. Cells were stimulated with the indicated concentrations of recombinant murine TNF $\alpha$ (R\&D Systems Inc., Minneapolis, MN, USA) and incubated for $4 \mathrm{~h}$ at $37^{\circ} \mathrm{C}$. As a control, purified IgG was used. The cells were then washed, fixed for $10 \mathrm{~min}$ in cold acetone and incubated with the polyclonal anti-ICAM antibody or the control $\operatorname{IgG}$ antibody $(10 \mu \mathrm{g} / \mathrm{ml})$ for $60 \mathrm{~min}$ at room temperature. Further processing was performed using the Vectastain biotin-avidin-peroxidase system (Vector Laboratories Inc., Burlingame, CA, USA) or the immunofluorescent secondary anti-rabbit antibody. Rat aortic rings cultured in medium were stimulated with $20 \mathrm{ng} \mathrm{TNF} \alpha / \mathrm{ml}$ for $4 \mathrm{~h}$ at $37^{\circ} \mathrm{C}$, frozen sections prepared and immunofluorescent staining performed as described above.

\section{Anti-ICAM-1 antibody}

New Zealand white rabbits of mixed sexes were immunized with $0.5 \mathrm{mg}$ recombinant soluble rat ICAM-1 subcutaneously using Freund's complete adjuvant (Lampire Biological Laboratories Inc., Pipersville, PA, USA). The animals were boostered every 4 weeks until an acceptable titer $\left(>10^{6}\right)$ was achieved. The antibody did not demonstrate cross-reactivity with E-selectin, P-selectin or $\beta$-integrins (data not shown). When used, mouse anti-ICAM-1 monoclonal antibody 1A29 was a gift from Dr. Masayuki Miyasaka (Osaka University, Osaka, Japan).

\section{Animal model of lung injury}

275-300 g male Long-Evans rats (Harlan Industries Inc., Rochester, MI, USA) were anesthetized with ketamine and lung injury was induced by intratracheal instillation of $150 \mu \mathrm{g}$ LPS (from E. coli, serotype $055: B 5)$, in $300 \mu \mathrm{l}$ PBS via an intratracheal catheter. Animals were sacrificed at given time points. To prepare lung homogenates, the vascular and bronchoalveolar areas of lungs were flushed before en bloc removal of lungs. For immune complex-induced alveolitis, rabbit polyclonal IgG rich in antibody to BSA (anti-BSA) was used [14]. Rabbit IgG anti-BSA $(2.5 \mathrm{mg})$ in a final volume of $300 \mu \mathrm{l}$ of PBS was instilled via an intratracheal catheter during inspiration. Immediately thereafter, $10 \mathrm{mg}$ BSA was injected intravenously. 


\section{Lung homogenates from LPS and IgG immune complex-injured lungs}

LPS lung injury was induced according to the protocol described above. The rats were sacrificed at $4 \mathrm{~h}$. Lungs homogenized in PBS containing $10 \mathrm{mM}$ 3-[(3-chloramidopropyl)dimethylammonio]-1-propane sulfonate (CHAPS) (Sigma Co., St. Louis, MO, USA), $20 \mu \mathrm{g} / \mathrm{ml}$ aprotinin (Boehringer Co.) $20 \mu \mathrm{g} / \mathrm{ml}$ bestatin (Sigma Co.) [15], $20 \mu \mathrm{g} / \mathrm{ml}$ leupeptin (Boehringer Co.) and $20 \mu \mathrm{l} 0.1 \mathrm{M}$ phenylmethylsulfonyl fluoride (PMSF) (Sigma Co.). The samples were pulse-homogenized with a homogenizer at maximum speed. The same procedure was performed with IgG immune complex-injured lungs (0, 2, 4, 6 and $8 \mathrm{~h}$ ). The total volume for each lung homogenate was $10 \mathrm{ml}$.

\section{Isolation of rat alveolar macrophages}

Alveolar macrophages were isolated from BAL fluids of rats as described previously [16]. Anesthetized rats were exsanguinated and a tracheotomy was performed. The lungs were lavaged 3 times with $10 \mathrm{ml}$ of PBS, this fluid then being centrifuged at 1500 RPM for $10 \mathrm{~min}$. The resuspended macrophages were again subjected to centrifugation and finally diluted to achieve a concentration of $1 \times 10^{6}$ cells $/ \mathrm{ml}$.

\section{ELISA with lung homogenates}

ELISA was performed in a similar way as described earlier [15]. 96 well plates (Nunc. Co.) were coated with polyclonal antibody $2 \mu \mathrm{g} / \mathrm{ml}$ in binding buffer and incubated overnight. All washing steps were performed with PBS/0.2\% Tween. A blocking step followed, using PBS containing $1 \%$ bovine serum and $0.05 \%$ Tween $\left(27^{\circ} \mathrm{C}\right.$ for $\left.30 \mathrm{~min}\right)$. Standards and samples were loaded and incubated for $1 \mathrm{~h}$ at $37^{\circ} \mathrm{C}$. The detecting biotinylated antibody was incubated for $1 \mathrm{~h}$ at $37^{\circ} \mathrm{C}$ at a concentration of $1 \mu \mathrm{g} / \mathrm{ml}$. Streptavidin-horseradish peroxidase (Pierce Co. $)$ was added $\left(0.1 \mathrm{mg} / \mathrm{ml}, 15 \mathrm{~min}, 37^{\circ} \mathrm{C}\right)$ and plates were developed with $O$-phenylenediamine dihydrochloride. The reaction was stopped by addition of sulfuric acid and the optical density determined at $490 \mathrm{~nm}$.

\section{$R N A$ extraction, reverse transcriptase (RT)-PCR, Northern blot and quantitative analysis of the PCR product}

Whole lungs were homogenized, and RNA extracted with RNA solubility buffer (RNAZOL) (Gibco-BRL Co. Inc.) according to previous studies [17]. RNA was purified over oligo-dT cellulose (Invitrogen Inc.). The final amount of mRNA isolated was between 5 and $30 \mu \mathrm{g}$. RT-PCR was performed according to the protocol described in the cDNA-cycle kit (Invitrogen Inc.). In the case of whole-lung mRNA, the reaction was performed with oligo-dT primers and with random primers when cDNA was used as the starting material. The reaction was carried out for two 1 -h cycles at $42{ }^{\circ} \mathrm{C}$ with avian myeloblastosis virus (AMV) reverse transcriptase. The final product was precipitated using yeast-tRNA as carrier and resuspended in $30 \mu \mathrm{l}$ double distilled water.

The PCR amplifications were performed using 1.5 Units Taq polymerase (Gibco Inc.), $50 \mu \mathrm{M}$ dNTPs (nucleoside triphosphate), $2 \mathrm{mM}$ magnesium chloride and $1 \mu \mathrm{l}$ of the different dilutions of cDNA templates. The total reaction volume was $50 \mu \mathrm{l}$ in each MicroAmp ${ }^{\mathrm{TM}}$ Reaction Tube (Perkin Elmer Co., Norwalk, CT, USA). All amplification and hybridization reactions were performed in a GeneAmp (IN) PCR System 9600 (Perkin Elmer Co.). The following PCR primers with the corresponding annealing temperatures were used:

Biotin-5'-ATGGCTTCAACCCGTGCCAGGC- $3^{\prime}$ and 5'-TCAGGGAGGCGGGGCTTGTAC- $3^{\prime}, 64^{\circ} \mathrm{C}$

Amplification protocols utilized the following conditions: 30 cycles at $94{ }^{\circ} \mathrm{C}$ for $30 \mathrm{~s}$, specific annealing temperature for $1 \mathrm{~min}$, and at $72{ }^{\circ} \mathrm{C}$ for $1 \mathrm{~min}$, followed by a final incubation at $72{ }^{\circ} \mathrm{C}$ for $10 \mathrm{~min}$. For the
Noerhern blot $12 \mu \mathrm{g}$ total RNA was electrophoresed in a $1.5 \%$ agarose gel containing formaldehyde and transferred to a nylon membrane. The blot was hybridized overnight with $1.5 \times 10^{7} \mathrm{cpm}\left({ }^{32} \mathrm{P}(\mathrm{dCTP})\right)$ labeled oligonucleotides using previously described methods [18]. The quantitative analysis of the PCR product required hybridization of the products with oligonucleotides, labelled with tris 2,2 (bipyridine ruthenium (II) chelate (TBR). A bead capture reaction was used and electrochemiluminescence PCR products were quantitated in the QPCR System $5000^{\mathrm{TM}}$ (Perkin Elmer Co.). Hybridization reactions were carried out using the following temperature program: $94{ }^{\circ} \mathrm{C}$ for $2 \mathrm{~min}$ to denature the PCR product and $55^{\circ} \mathrm{C}$ for $3 \mathrm{~min}$ to hybridize the biotinylated strand with the TBR-labeled oligonucleotide. The sequence for the TBR-labeled probes were as follows:

\section{TBR-5'-CAGTGTCTCATTCCCACGGAG- $3{ }^{\prime}, 64^{\circ} \mathrm{C}$.}

The hybridization reaction contained $2-4 \mu \mathrm{l}$ of the PCR product, $10-20 \mathrm{pM}$ of TBR-labeled probe and hybridization buffer in a final volume of $50 \mu \mathrm{l}$. For the bead capture reaction, $15 \mu \mathrm{l}$ or $30 \mu \mathrm{l}$ of a $2 \mu \mathrm{g}$ / $\mu 14.5 \mu \mathrm{m}$ magnetic polystyrene bead suspension (Dynabeads M450, Dynal Co., Great Neck, NY, USA) was added directly in the PCR tube. The capture reaction was carried out for $20 \mathrm{~min}$ at $55^{\circ} \mathrm{C}$. Thereafter the whole reaction mix was immediately transferred to a separate quick PCR (QPCR) System 5000 tube for measurement of the electrochemiluminescent signal.

\section{Statistical analysis}

All experiments were performed in duplicate. Data were analyzed by two-tailed Student's t-test. Data were considered statistically significant if p-values were less than 0.05 .

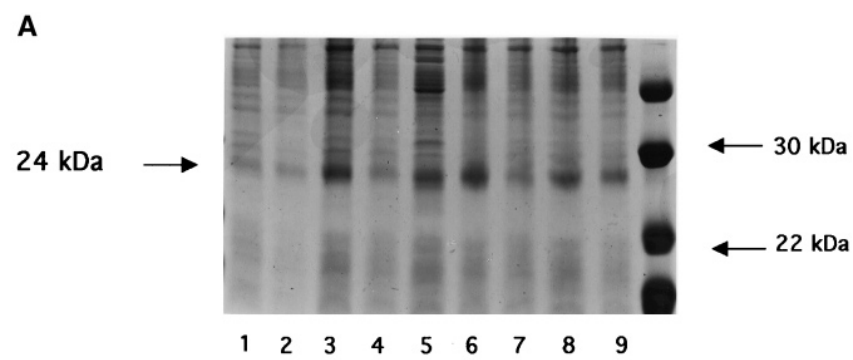

B

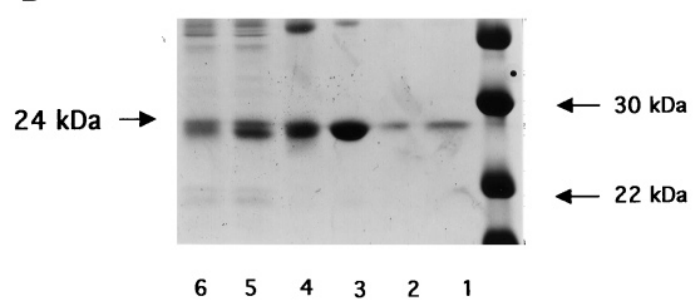

Fig. 1. pLysS bacteria were stimulated and analyzed at different densities (determined by O.D.) for different time periods (h). The soluble products were analyzed on $15 \%$ SDS/PAGE (A). The first three lanes were samples from bacteria suspensions with an optical density (O.D.) of 0.7 , stimulated for $1 \mathrm{~h}$ (lane 1), $2 \mathrm{~h}$ (lane 2 ) and $3 \mathrm{~h}$ (lane 3 ). In lanes 4-6 (O.D. = 0.7) and 7-9 (O.D. =0.8), stimulation was for 2 or $3 \mathrm{~h}$. There was an increase of protein expression with time. The O.D. of a given sample did not seem to correlate with protein expression. In further studies using $15 \%$ SDS/PAGE, products were eluted with three different concentrations of imidazole under nonreducing and reducing conditions (B). The following elution conditions (including imidazole concentrations) were employed: lane 1: $100 \mathrm{mM}$, nonreducing; lane 2: $100 \mathrm{mM}$ reducing; lane 3: $200 \mathrm{mM}$, nonreducing; lane 4: $200 \mathrm{mM}$, reducing; lane 5: $300 \mathrm{mM}$, nonreducing; lane 6: $300 \mathrm{mM}$ reducing. 


\section{Results}

Expression of soluble rat ICAM-1 in a bacterial system

A rat ICAM-1 expression vector was created by ligating a 618 bp cDNA containing the ICAM-1 binding CD11a/CD18 sites for (LFA-1) and CD11b/CD18 (Mac-1) into pET and pPBac vectors. This cDNA was about one fourth the full length of ICAM-1 (2680 bp). The chances to obtain a soluble protein were increased with this construct. Sequencing of the construct demonstrated the correct orientation of the insert in the vector. Our $618 \mathrm{bp}$ cDNA construct was totally identical (data not shown) with the same region of the full rat ICAM-1 construct $(2680 \mathrm{bp})$, the sequence of which has already been published [7]. After transformation into E. coli pLysS, the cells were stimulated with IPTG $(0.4 \mathrm{mM}$ final concentration) for 1, 2 and $3 \mathrm{~h}$. Bacteria were lysed and the fractions analyzed by SDS/PAGE. Maximum expression of protein was found at $3 \mathrm{~h}$ (Fig. 1A). Purification of the soluble protein was performed using three different elution concentrations of imidazole (Fig. 1B). As seen in the Coomassie gel, the best yield was with $200 \mathrm{mM}$ imidazole (lanes 3, 4). In bacterial cultures, the final concentration of ICAM-1 was $0.5 \mathrm{mg} / \mathrm{liter}$. The insoluble ICAM-1 was purified and eluted with the same buffers containing $6 \mathrm{M}$ urea. Both proteins were in position at $24 \mathrm{kDa}$ instead of expected $23 \mathrm{kDa}$ position, due to the presence of the polyhistidine tail.

\section{Expression of soluble ICAM-1 by insect cells}

Using the $618 \mathrm{bp}$ PCR product and the pPBac vector, a transfer vector was created. In contrast to a previous study

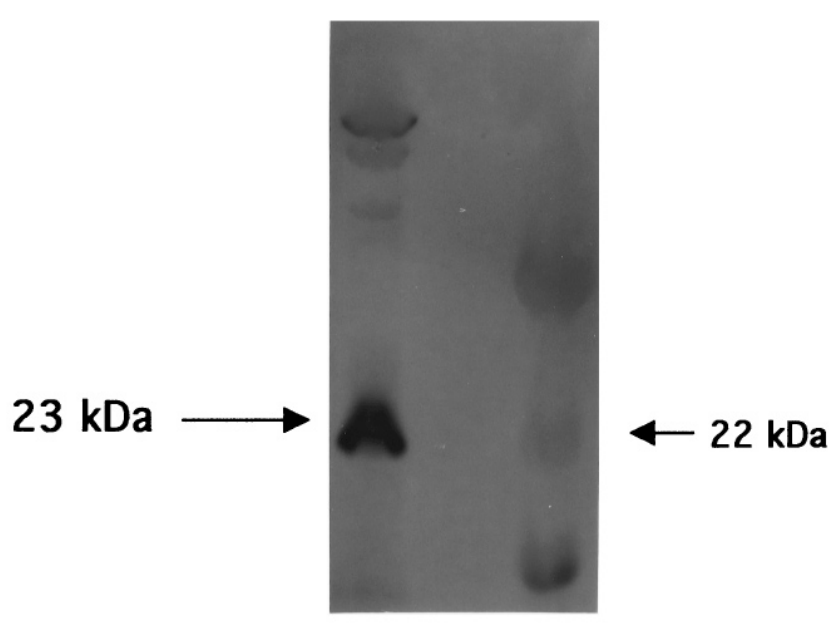

\section{3}

Fig. 2. Western blot analysis using polyclonal anti-ICAM-1 antibody. Using 15\% SDS/PAGE, lysed, infected insect cells products were transblotted and Western analysis performed. Lane 1 shows protein expression of ICAM- 1 by baculovirus at the $23 \mathrm{kDa}$ position; lane 2 fails to show protein expression in material obtained from uninfected cells; lane 3 contains the low molecular weight marker. with human ICAM-1 in which several constructs were found to be expressed [19], only one construct was expressed by the baculovirus expression system in this study. The main objective was aimed at developing a polyclonal antibody rather than a functionally active protein. Western blot analysis of cell products obtained using recombinant virus or a wildtype virus (control) demonstrated the expressed protein to be of the correct size (Fig. 2, lane 1). The control virus did not yield a product detected by Western blot analysis (Fig. 3, lane 2). Low molecular weight markers are shown in lane 3 . The protein was purified by dialyzing and using an affinity column loaded with the antibody to ICAM-1. As described elsewhere, the insect cell system is very effective in generating large quantities of proteins $[19,20]$ along with a functionally active protein [21]. We achieved $2 \mathrm{mg}$ soluble ICAM-1/liter using these methods. This material was employed for the generation of rabbit polyclonal antibody.

\section{Quantitation of ICAM-1 expression in vitro}

Western blot analysis was performed to determine if the polyclonal antibody recognized the same protein as the monoclonal 1A29 anti-ICAM-1 antibody [15]. Using whole lung homogenates from $4 \mathrm{~h}$ inflamed rat lungs as a source for full length rat ICAM-1, both antibodies recognized the same
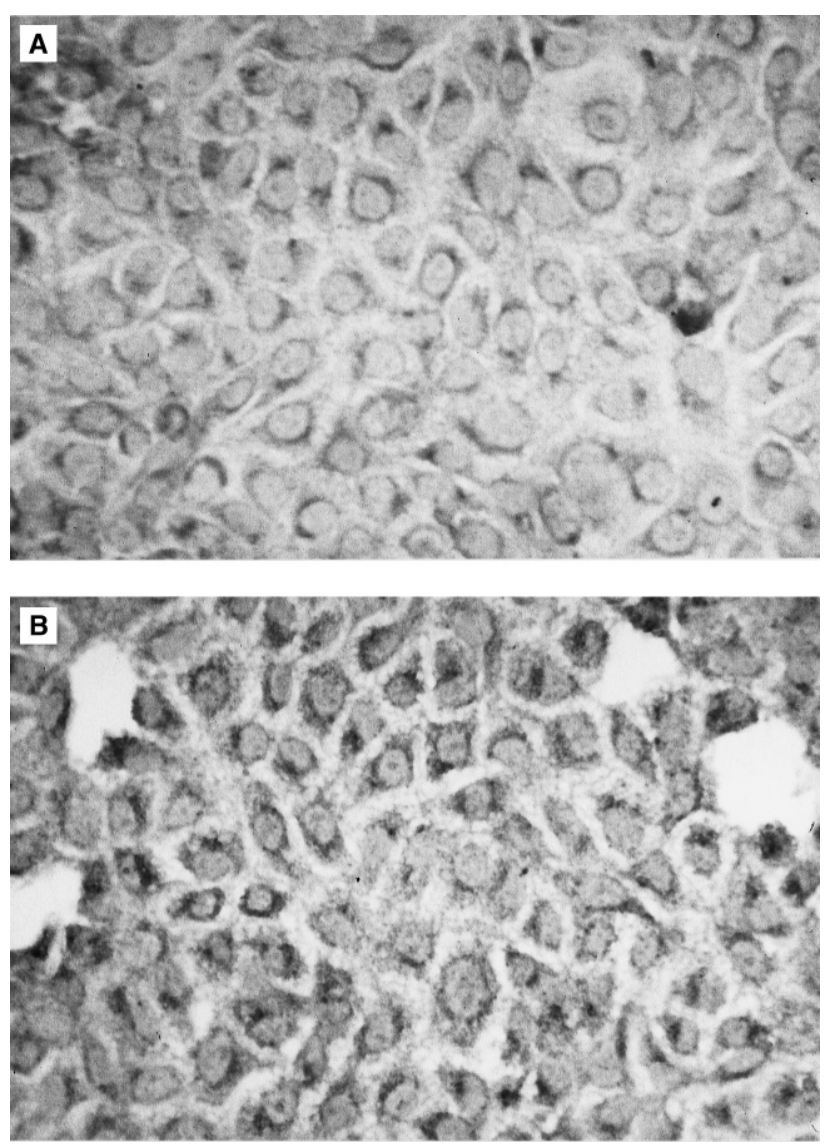

Fig. 3. Immunohistochenmical staining of unstimulated RPAEC Staining for constitutive ICAM-1 expression was visible (A); with stimulation by $\mathrm{TNF} \alpha(50 \mathrm{ng} / \mathrm{ml})$, ICAM-1 expression increased (B). 
protein with the size of $97 \mathrm{kDa}$ (data not shown). This size is consistent with previously published data [22], with a band of 91-97 kDa position. For immunostaining of RPAEC, cells were stimulated for $4 \mathrm{~h}$ in the presence or absence of murine $\mathrm{TNF} \alpha(50 \mathrm{ng} / \mathrm{ml})$. In Fig. 3A in which the newly prepared rabbit anti-ICAM-1 IgG was used, the staining of nonstimulated cells was found, apparently detecting constitutive ICAM-1. In Fig. 3B more intense staining for ICAM-1 was detected. Quantitation of these differences in ICAM-1 content is described below.

Immunofluorescence staining was performed on frozen sections of rat aortic rings which were stimulated in vitro with $\mathrm{TNF} \alpha(20 \mathrm{ng} / \mathrm{ml}$ for $4 \mathrm{~h})$. Fig. 4 shows the staining of a stimulated aortic ring for ICAM-1. The endothelial surface stained intensely, but, there was also some staining of smooth muscle cells. ICAM-1 expression on vascular smooth cells has been described previously [23]. Control (non-stimulated) rings did not show evidence of fluorescence (data not shown). When LPS was used to stimulate RPAEC, there was a significant increase $(50 \%)$ in ICAM-1 content, reaching a plateau after $6 \mathrm{~h}$ (Fig. 5A). Using different LPS concentrations, ICAM-1 expression on RPAEC was maximal at the LPS concentration of $10 \mu \mathrm{g} / \mathrm{ml}$ (Fig. 5B).

Monolayers of alveolar macrophages from normal rat lungs were prepared using 96 well plates and stimulated with increasing concentrations of TNF $\alpha(0-100 \mathrm{ng} / \mathrm{ml})$. The time course for LPS-induced expression of ICAM-1 on alveolar macrophages showed a plateau at $2 \mathrm{~h}$ (70\% increase) (Fig. 6A). Maximal stimulation (40\% increase) in ICAM-1 expression was reached at $10 \mathrm{ng} \mathrm{TNF} \alpha / \mathrm{ml}$ (Fig. 6B).

\section{Quantitation of ICAM-1 $\mathrm{mRNA}$ and protein expression in vivo}

Homogenates from IgG immune complex-injured lungs were evaluated by Northern blot analysis and with quantitative PCR at $0,2,4,6$ and $8 \mathrm{~h}$ after initiation of the inflammatory reactions. As expected, by Northern blot analysis low constitutive expression of ICAM-1 mRNA was found in normal lungs, with a 12 -fold upregulation $4 \mathrm{~h}$ after initiation

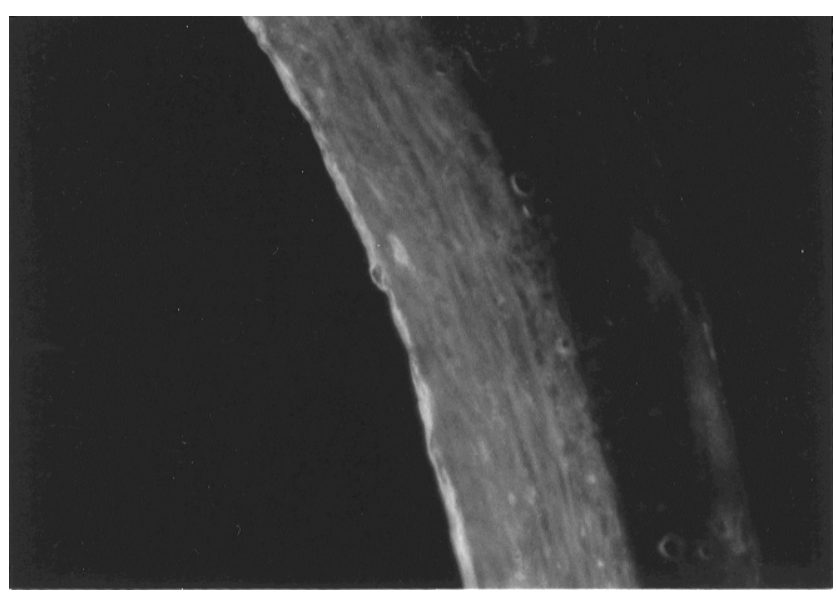

Fig. 4. Immunofluorescence staining of $\mathrm{TNF} \alpha$-stimulated rat aortic ring, showing expression of ICAM-1 on endothelial and smooth muscle cells. of the reactions (Fig. 7A). A comparison of Northern blot analysis to quantitative PCR is shown in Fig. 7 (A, B). By $6 \mathrm{~h}$ of lung injury, ICAM-1 mRNA as assessed by quantitative PCR decreased to baseline levels. Data derived from the two methods of mRNA measurement were reasonably comparable. To determine whole lung ICAM-1 protein content, lungs were homogenized at indicated time points and ELISA performed. The greatest increase in total ICAM-1 protein was demonstrated at $6 \mathrm{~h}$ (Fig. 7C), following the earlier increase in mRNA for ICAM-1. As indicated above, at least two different cell sources for lung ICAM-1 have been identified: alveolar macrophages and vascular endothelial cells.

\section{Discussion}

Rat ICAM-1 was expressed in order to develop an ELISA for measurement of ICAM-1 protein as well as to raise a polyclonal antibody for further direct protein studies. ICAM-1 was expressed in vitro in two different systems. In
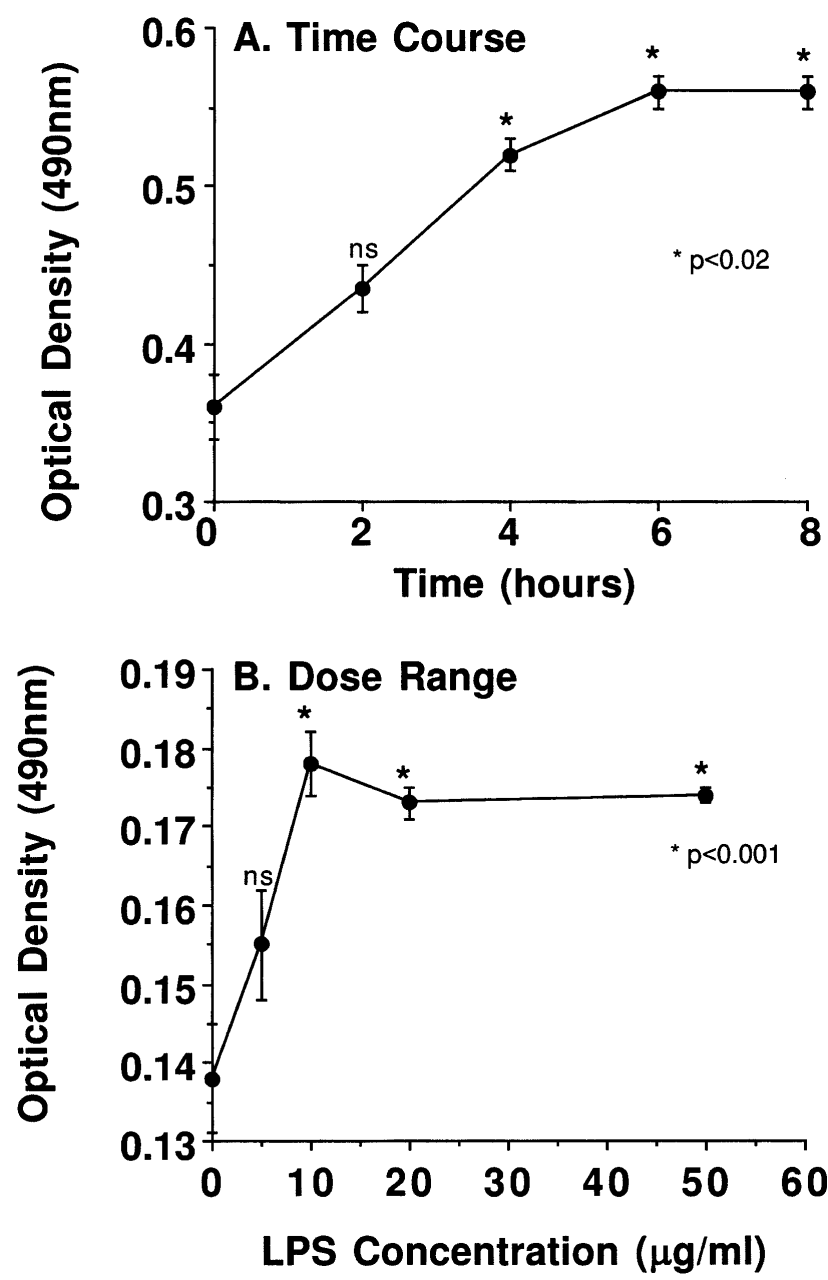

Fig. 5. Time course for ICAM-1 expression in LPS-stimulated (10 $\mu \mathrm{g} /$ ml) RPAEC (A). Maximum expression was found at $6 \mathrm{~h}$. RPAEC stimulated with increasing concentrations of LPS $(0-50 \mu \mathrm{g} / \mathrm{ml})(B)$. Maximum expression was found when the concentration of LPS was $10 \mu \mathrm{g} / \mathrm{ml})$. 

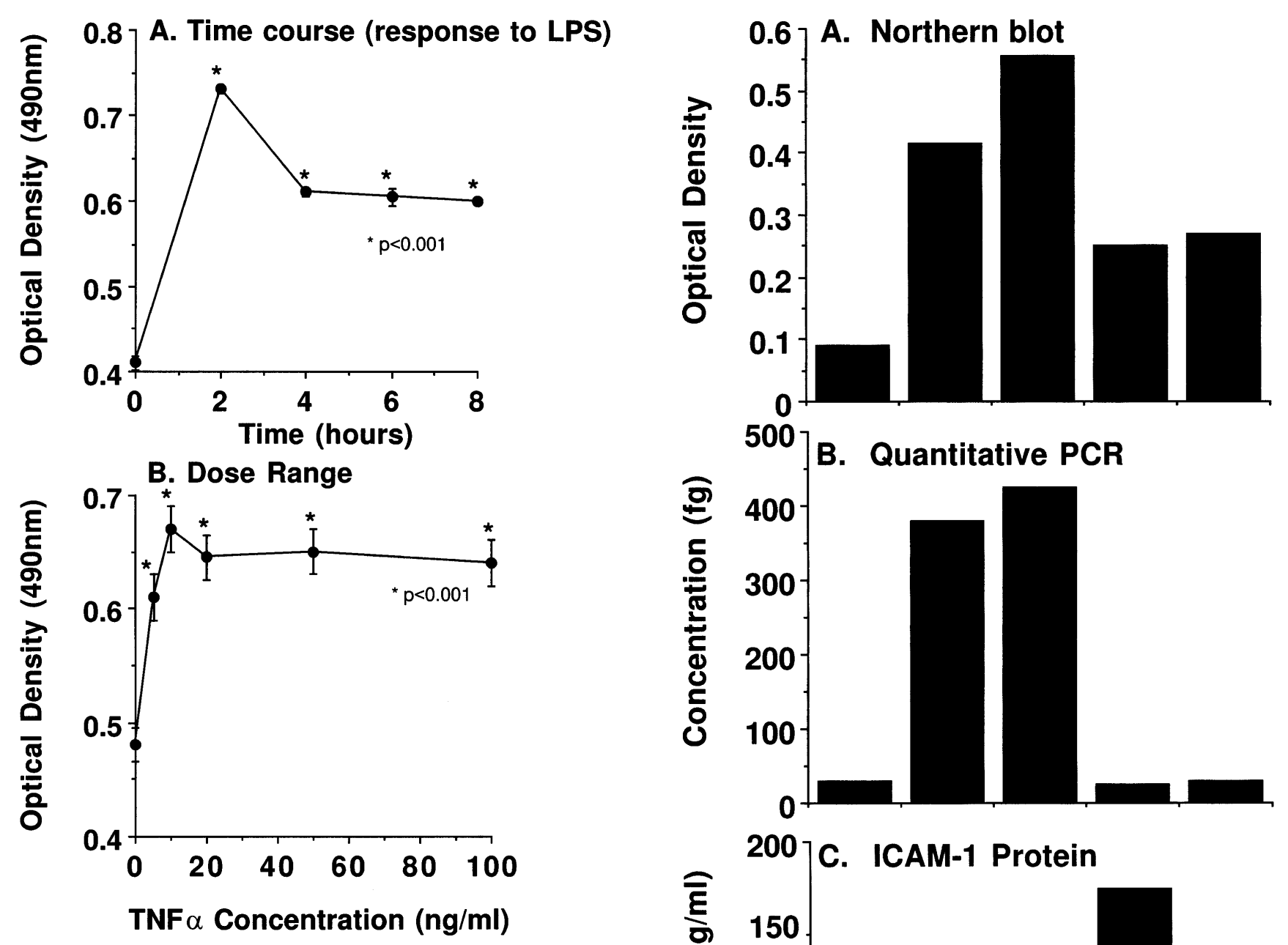

Fig. 6. Expression of ICAM-1 in rat alveolar macrophages. Maximum expression was reached after $2 \mathrm{~h}(\mathrm{~A})$. Using a dose range of TNF $\alpha$ with the end-point of $2 \mathrm{~h}$, maximal expression of ICAM-1 occurred at a dose of $\mathrm{TNF} \alpha$ of $10 \mathrm{ng} / \mathrm{ml}(\mathrm{B})$.

comparing the bacterial pET and the baculovirus expression systems, the latter revealed a higher yield and purity but was much more time-consuming. The baculovirus system, however, may have advantages over the pET system with regard to the function of the expressed protein due to posttranslational modifications of the protein in the insect cells. Successful purification of a membrane-bound protein begins with selection of an appropriate detergent and establishment of the solubilization conditions [24]. We found that CHAPS was best detergent-suited for our purposes because it was milder than a detergent like SDS, which tended to activate proteases, resulting in cleavage of ICAM-1. To prevent proteolysis, a mixture of bestatin, leupeptin, aprotinin and PMSF was used. This technique of protein extraction from lung tissue has become a common procedure and has been repeatedly used [18]. When ICAM-1 content was evaluated in whole lung homogenates, in the absence of this mixture of inhibitors, Western blots consistently showed an ICAM-1 species considerably below the expected $97 \mathrm{kDa}$ position (data not shown).

Endothelial (RPAEC) ICAM-1 expression in vitro was assessed in RPAEC. Following LPS stimulation $(5 \mu \mathrm{g} / \mathrm{ml})$
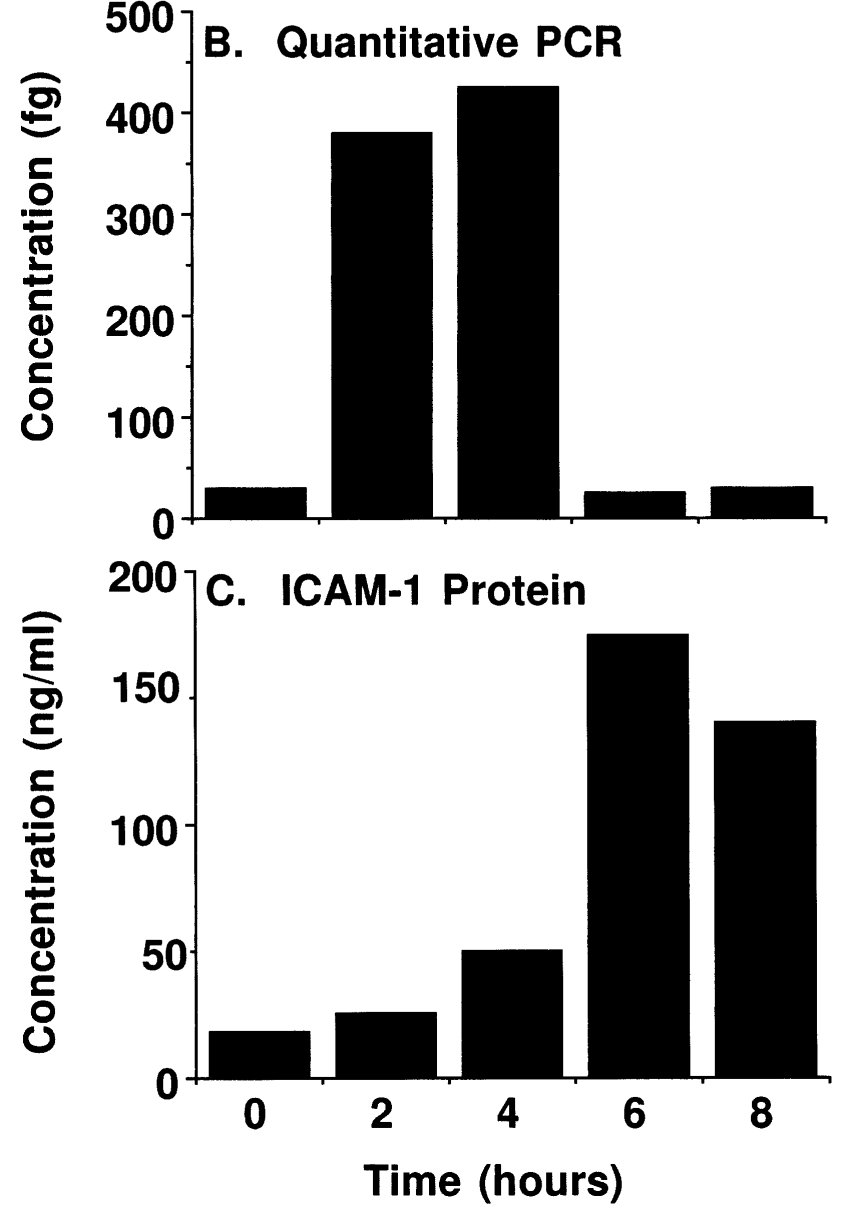

Fig. 7. Northern blot analysis with mRNA for ICAM-1 in a time-course for IgG immune complex-induced lung injury (A). Similar analysis was carried out using quantitative PCR (B). ICAM-1 protein content in whole lung homogenates was measured by ELISA (C).

for 2, 4, 6 and $8 \mathrm{~h}$, a plateau in expression of protein being found after $6 \mathrm{~h}$. In contrast to these in vitro results, in LPSinjured lungs in vivo, ICAM-1 message peaked at $4 \mathrm{~h}$ while protein expression was detected at $2 \mathrm{~h}$ but persisted for as long as $8 \mathrm{~h}$ [15]. Similar results have been obtained with TNF $\alpha$ stimulated human umbilical vein endothelial cells (HUVEC) [13,25]. In the study by Wertheimer et al. [25] there was an early $(2 \mathrm{~h})$ peak and followed later by a plateau for ICAM-1 mRNA expression in TNF $\alpha$-stimulated 
HUVEC. We saw a similar pattern of ICAM-1 expression in rat alveolar macrophages, with a plateau after $2 \mathrm{~h}$ of stimulation [15]. When canine alveolar macrophages were stimulated in vitro with LPS over $24 \mathrm{~h}$, there was a steady increase of ICAM-1 expression [26]. This result could be due to the difference in LPS concentration used $(5 \mathrm{ng} / \mathrm{ml}$ versus $5 \mu \mathrm{g} / \mathrm{ml}$ in our studies). At the higher concentration, the macrophages appeared to be maximally stimulated, which may have resulted in earlier down-regulation of the ICAM-1 response.

The quantitative PCR method used in this study correlated well with the data obtained by Northern blot analysis and offers the significant advantage for more accurate quantitation of mRNA levels rather than assessing relative expression levels $[27,28]$. The electrochemiluminescence detection of PCR products was time-efficient and highly specific due to the TBR-labeled oligonucleotides and provides a valuable tool for evaluation of mRNA regulation $[29,30]$.

Interestingly, there was only a slight increase of ICAM-1 expression in the endothelial cell cultures compared to in vivo ICAM-1 upregulation in whole lungs. This could have several explanations: 1) in cell culture, there is no interaction between different cell types, this interaction being required for optimal expression of ICAM-1;2) apart from endothelial cells or alveolar macrophages, other cells, such as epithelial cells, may contribute to the total production of ICAM-1 in the lung; 3) in cell culture with confluent monolayers, only the apical part of the cell is studied with ELISA techniques, omitting the basolateral area of the cell. In conclusion, soluble rat ICAM-1 was expressed in two different expression systems and a new polyclonal antibody was generated. The cDNA, the recombinantly expressed ICAM-1, and the polyclonal antibody developed represent useful tools in the elucidation of the role of this adhesion molecule. These reagents have permitted a detailed analysis rat ICAM-1 expression in inflammatory processes. Expanding these studies should add additional information in characterizing the role of ICAM-1 expression in lung inflammation.

\section{References}

[1] Barton RW, Rothlein R, Ksiazek J, Kennedy C. The effect of anti-intercellular adhesion molecule-1 on phorbol-ester-induced rabbit lung inflammation. J Immunol 1989;143:1278-82.

[2] Mulligan MS, Wilson GP, Todd RF, Smith CW, Anderson DC, Varani $\mathrm{J}$, et al. Role of beta 1, beta 2 integrins and ICAM-1 in lung injury after deposition of $\operatorname{IgG}$ and $\operatorname{IgA}$ immune complexes. J Immunol 1993;150:2407-17.

[3] Seekamp A, Mulligan MS, Till GO, Smith CW, Miyasaka M, Tamatani T, et al. Role of beta 2 integrins and ICAM-1 in lung injury following ischemia-reperfusion of rat hind limbs. Am J Pathol 1993;143:464-72.

[4] Albelda SM. Endothelial and epithelial cell adhesion molecules. Am J Respir Cell Mol Biol 1991;4:195-203.

[5] Ward PA, Mulligan MS, Vaporciyan AA, Eppinger MJ. Adhesion molecules in experimental lung inflammatory injury. In: Ward PA, Fantone JC, editors. Adhesion molecules and the lung. New York, Basel, Hong Kong: Marcel Drekker, 1996:150-76.

[6] Wawryk SO, Novotny JR, Wicks IP, Wilkinson D, Maher D, Salvaris E, et al. The role of the LFA-1/ICAM-1 interaction in human leukocyte homing and adhesion. Immunol Rev 1989;108:135-61.

[7] Kita Y, Takashi T, Iigo Y, Tamatani T, Miyasaka M, Horiuchi T. Sequence and expression of rat ICAM-1. Biochem Biophys Acta 1992;1131:108-10.

[8] Miller LK. Baculoviruses as gene expression vectors. Annu Rev Microbiol 1988;42:177-99.

[9] Smith GE, Summers MD, Fraser MJ. Production of human beta interferon in insect cells infected with a baculovirus expression vector. Biotechnology 1992;24:434-43.

[10] Jones ML, Mulligan MS, Flory CM, Ward PA, Warren JS Potential role of monocyte chemoattractant protein $1 / \mathrm{JE}$ in monocyte/macrophage-dependent IgA immune complex alveolitis in the rat. J Immunol 1992;149:2147-54.

[11] Maniatis T, Fritsch EF, Sambrook J. Molecular cloning: A laboratory manual. Cold Spring Harbor: Cold Spring Harbor Lab., 1982:73-82.

[12] Laemmli UK. Cleavage of structural proteins during the assembly of the bacteriophage T4. Nature 1970;227:680-5.

[13] Muligan MS, Vaporciyan AA, Miyasaka M, Tamatani T, Ward PA. Tumor necrosis factor $\alpha$ regulates in vivo intrapulmonary expression of ICAM-1. Am J Pathol 1993;142:1739-49.

[14] Johnson KJ, Ward PA. Acute immunologic pulmonary alveolitis. J Clin Invest 1974:54:349-57.

[15] Beck-Schimmer B, Schimmer RC, Warner RL, Schmal H, Nordblom G, Flory CM, et al. Expression of lung vascular and airway ICAM-1 after exposure to bacterial lipopolysaccharide. Am J Respir Cell Mol Biol 1997;17:344-52.

[16] Ward PA, Duque RE, Sulavik MC, Johnson KJ. In vitro and in vivo stimulation of rat neutrophils and alveolar macrophages by immune complexes. Production of O2- and $\mathrm{H} 2 \mathrm{O} 2$. Am J Pathol 1983;110:297-309.

[17] Chirgwin JM, Pryzbyla AE, MacDonald RJ, Rutter WJ. Isolation of biologically active ribonucleic acid from sources enriched in ribonuclease. Biochemistry 1979;18:5294-9.

[18] Shanley TP, Schmal H, Friedl HP, Jones ML, Ward PA. Regulatory effects of intrinsic IL-10 in IgG immune complex-induced lung injury. J Immunol 1995;154:3453-60.

[19] Cobb RR, Dubins JS, Warner J, Molony L. Functional expression of soluble ICAM-1 by baculovirus-infected Sf9 cells. Biochem Biophys Res Commun 1985;185:1022-33.

[20] Zhao Y, Sane DC. Expression of a recombinant baculovirus for vitronectin in insect cells: Purification, characterization of posttranslational modifications and functional studies of the recombinant protein. Arch Biochem Biophys 1993;304:434-42.

[21] Shridhar P, Hasnain SE. Differential secretion and glycosylation of recombinant human chorionic gonadotropin (bhCG) synthesized using different promoters in the baculovirus expression vector system. Gene 1993;131:261-4.

[22] Tamatani T, Miyasaka M. Identification of monoclonal antibodies reactive with the rat homolog of ICAM-1, and evidence for a differential involvement of ICAM-1 in the adherence of resting versus activated lymphocytes to high endothelial cells. Int Immunol 1990;2:165-71.

[23] Ikeda U, Ikeda M, Seino Y, Takahashi M, Kasahara T, Kano S, et al. Expression of intercellular adhesion molecule-1 on rat vascular smooth muscle cells by pro-inflammatory cytokines. Atherosclerosis 1993;104:61-8.

[24] Hjelmeland LM. Solubilization of native membrane proteins. Methods Enzymol 1990;182:253-64.

[25] Wertheimer SJ, Meyers CL, Wallace RW, Parks TP. Intercellular adhesion molecule-1 gene expression in human endothelial cells. J Biol Chem 1992;267:12030-5.

[26] Grigg J, Kukielka GL, Berens KL, Dreyer WJ, Entman ML, Smith CW. Induction of intercellular adhesion molecule- 1 by lipopolysaccharide in canine alveolar macrophages. Am J Respir Crit Care Med 1994;11:304-11.

[27] Dallman MJ, Montgomery MJ, Larsen CP, Wanders A, Wells AF. Cytokine gene expression: Analysis using Northern blotting polymerase chain reaction and in situ hybridization. Immunol Rev 1995;119:163-79. 
[28] Salomon RN, Underwood R, Doyle MV, Wang A, Libby P. Increased apolipoprotein $\mathrm{E}$ and $\mathrm{c}-\mathrm{fms}$ gene expression without elevated interleukin 1 or $6 \mathrm{mRNA}$ levels indicates selective activation of macrophage functions in advanced human atheroma. Proc Natl Acad Sci 1987:7160-4.

[29] Kenten JH, Gudibande S, Link J, Willey JJ, Curfman B, Major $\mathrm{EO}$, et al. Improved electrochemiluminescent label for DNA probe assays: Rapid quantitative assays of HIV-1 polymerase chain reaction products. Clin Chem 1992;38:873-9.

[30] DiCesare J, Grossmann B, Katz E, Picozza E, Ragusa R, Woudenberg T. A high-sensitivity electrochemiluminescencebased detection system for automated PCR product quantitation. Biotechniques 1993;15:152-7. 